\title{
Healthy Dwelling Design at Wetland Area
}

\author{
Widya Fransiska F.Anwar ${ }^{1, *}$ \\ ${ }^{1}$ Department of Architecture, Faculty of Engineering, Universitas Sriwijaya, J1. Raya Prabumulih \\ Km.32 Ogan Ilir-South Sumatera-Indonesia
}

\begin{abstract}
Palembang is one of the cities in Indonesia that is dominated by wetlands. City development transforms wetland area to be the location of two types of dwellings; settlement and housing. As the wetland nature is watery covered, dwellings deal with the issue of healthy environment. This paper aims to find out the important aspects for developing healthy dwelling in wetlands. To achieve the aim, the study elaborated the natural character of wetland in Palembang, regulations and architectural theory related to dwelling design. The field observation also conducted to complement the elaboration. The analysis was done qualitatively in four variables; the nature of residential area, structural system, space order and building performance. The result shows that healthy dwelling at the wetland environment design can be done by considering the periodic puddles, stilt structure, physical comfort and flexible ordering system. This study suggests an emphasis on durable structure and flexible space order in designing healthy dwelling at wetlands.
\end{abstract}

\section{Introduction}

The wetland with watery covered and low topography is not a preferable location to build a place for living. For a city which is dominated by wetlands like the city of Palembang, the development of wetlands is inevitable. The development of urban settlements in Palembang began at the riverside area [1.2] with the tributaries of the Musi River as economic driving point. [3]. As the population increases, the physical development reached the wetland area especially for settlement or housing. The development at wetland area does not consider the natural and ecological aspects of the area [4]. The development is less considered the quality of environment. This results in the increasing of slum area and the decreasing of wetland ability to catch the runoff water. Therefore, the water covered nature of wetland lead the issue of healthy dwelling. Dwelling refers to any habitation places including the settlement and housing. This paper aims to elaborate the important aspects for developing healthy dwelling in wetlands. To achieve the aim, the study elaborated the natural character of wetland in Palembang, regulations and architectural theory related to dwelling design and observed the settlement and housing at wetland area.

By nature, wetlands are transitional areas between aquatic and terrestrial systems that have physical, chemical and biological characteristics. Wetlands should have at least one of

\footnotetext{
${ }^{*}$ Corresponding author: widyafransiska@ft.unsri.ac.id
} 
the following characteristics: (1) periodically flooded land (2) undried-hydric soil (3) nonsoil saturated material or closed with shallow water at a seasonal time during the year. Natural puddle wetlands occur continuously due to clogged natural drainage. [5.6]

In Rams ar convention 1972, wetlands as water covered area were categorized as shallow open water and covered or saturated water area. The shallow open water consists of lakes, ponds, rivers and coastal fringes. The covered or saturated water is any land that regularly or intermittently covered or saturated by water such as marshes, bogs, swamps, flood plains and the like. [7] More detail, The Ministerial Decree of Environment Republic of Indonesia 5/2000 mentions the type of wetlands in Indonesia namely peat land, water catchment areas, river and lake, coastal, mangrove, and marshes.

Wetland has important role for environment. It is a buffer system for ecosystem life from chemicals, minerals or other toxic substances that are potentially harmful to the life of any terrestrial and aquatic ecosystems. Wetland also serves as water suppliers, flood control and sea water intrusion prevention. Wetland is highly sensitive to the negative effect of physical development. The development leads to the change runoff water flow. Based on its important role in the ecosystem, wetland development has been regulated by the government of Indonesia in various policies. The development of wetland must support its role as water catchment area. Every development plan at the wetland must be complemented by the environmental impact assessment (AMDAL) to make sure that it does not harm its natural balance. For riverbanks and coastal area, development should pay attention to the boundary of the river and coastal as protected area. (Article 9 of Government Regulation 27/ 1991; Articles 14 and 16 of Presidential Decree 32/1990; Ministerial Decree of Environment5/2000).

In designing the dwelling, there is a theory of design that is being used for designing, named Vitruvius theory (1914). The theory of Vitruvius is presented by a philosopher named Vitruvius Pollio Markus in his book the ten book of architecture. This theory states that an appropriate architectural design must meets three basic requirement; firmit as, utility as and venust as. Firmit as is the principle of firmness and endurance (durability) that must be owned by a design work. It includes the structural and material systems. Venust as emphasizes the beauty and visual comfort of architectural design. Venust as underlines that a true design is one that has a pleasing and proportionate appearance. The utility as emphasizes the design capability that can fulfill the expected function and make the design can be used. This includes good space management, appropriate placement of functions and proper building systems and structures according to the building's technical requirements.[8]

Beside the Vitruvius theory, architectural design should meet the physical comfort criteria in building science. The design should let the building perform well based on three measurable comforts in building science namely thermal, visual and sound comfort. Thermal comfort is associated with temperature and humidity in the room. Visual comfort is associated with light levels that enter the room. Sound comfort refers to the pleasure of hearing that is desired and tolerated by the occupants of room. These three things are influenced by nature in the form of sunlight, rainfall, and wind flow and earthquake vibration. These three things, when considered with the proper arrangement, can cause physical comfort for occupants and lead to healthy micro environment inside and outside the building $[9,10]$

The criteria of healthy dwelling (read: house) design has mentioned in theories of design and regulated by the local authority. Essentially, the criteria of healthy dwelling design have mentioned in theory of Vitruvius and physical comfort. The venust as and firmitas support thermal and visual comfort for healthy environment inside the building. The unhealthy dwelling area is termed in regulation as slum area. As described in the 
Palembang Municipal Regulation 8/2016, a slum area is characterized as buildings that are located in high density areas. Most of these buildings have irregular arrangements, minimum fulfillment on space and technical requirements. The coverage of the road network and the low quality road surface environment also determines the slum definition. Further, the unavailability of infrastructure also determines the slum definition of a residential environment in terms of connectivity with urban drainage system and low quality of drainage construction, waste water and garbage management, and unavailability of fire protection facilities. A dwelling place is categorized as healthy environment if it has only few of these weaknesses stated on there gulation.

\section{Materials and Methods}

This paper aims to find out the important aspects for developing healthy dwelling in by elaborating wetland natural character, regulations and theories of design. Field observation was conducted at settlements as well as housing areas that were located on the wetlands in the city of Palembang. Qualitative descriptive analysis is done in four variables; the nature of residential area, structural system, space order and building performance. Figure 1 describes the methodology of study.

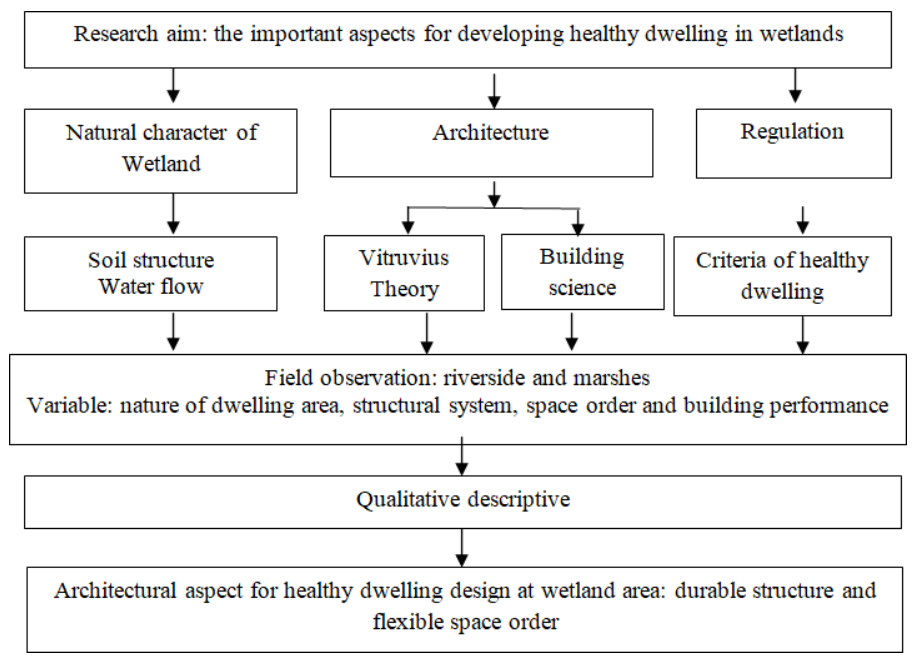

Fig. 1. Methodology of study

\section{Results and Discussions}

\subsection{Development of Dwelling in Palembang}

Palembang has two types of wetland, the riverbank and marshes. The development of urban settlements in Palembang began at the riverside area before the colonial era. Riverside was the initial city center in Palembang when the maritime lifestyle. The development was based on adaptation with wetland environment as proven by the stilt structured houses located at riverside and marshes. In colonial era, the street along the river was built and introduced the landed lifestyle. The new lifestyle introduced the masonry and concrete structure for buildings. 
As the population is increasing and the dry land is limited, the urban wetland becomes the location for housing and settlements. The wetlands are reclaimed to change the wetland into dry land. More buildings and infrastructure built by masonry and concrete structure are found at wetland area. The housing development at the wetland area reduces its ecological role as water catchment area. In the long run, the increasing fragmented wetland increase the risk flood due to its minimum ability to hold water. It is also happened at riverside settlement. As the location is at city center, the vacant spaces between buildings are filled by the new buildings. The space under the stilt structure is used as new unit of house or space extension of existing stilt house. This situation leads to higher building density at urban area.

As explained in the previous section, wetlands in Palembang are categorized as riverside and marshes. The dwellings at riverside area are the old and historical buildings with new ones built at vacant area of the settlement. Most of the houses are built by responding to the nature of wetland. On the other hand, the dwellings at marshes are modifying the nature of wetland. The housing area is built on the reclaimed marshes to accommodate landed lifestyle. Therefore, there are some differences among these two locations. Firstly, the design was based on different response to the nature of wetland. The riverside settlement has organic morphology form, following the natural landscape of the wetland area. The housing at reclaimed wetland has more patterned morphology form as result from the modification. Figure 1 shows the difference of morphology. The second difference is in design management. The riverside settlement was designed by the people based on local knowledge. The housing was designed by the developer based on modern knowledge. Therefore the modern infra structure at reclaimed wetland is relatively easier to build, maintain and manage.

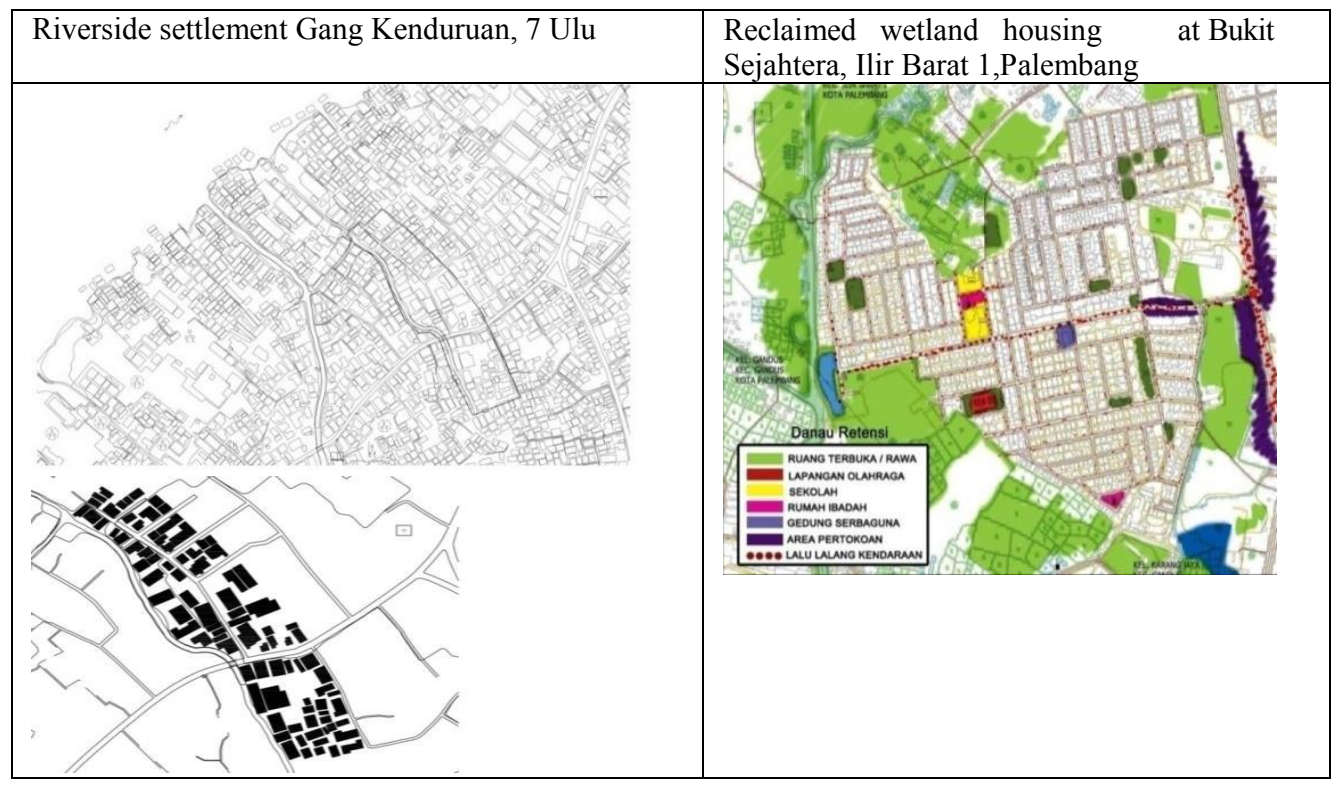

Fig. 2. The morphology differences among riverside settlement and reclaimed wetland housing 


\subsection{The Design for Healthy Dwelling at Wetland}

Referring to Vitruvius's theory, physical comfort theory and character of slum area, the design of healthy dwelling in wetlands should consider the nature of wetlands. Typical character of wetland creates a critical point in the execution of dwelling design including response to the water, sub structure, space arrangement, building system and residential appearance. Wetlands are always associated with puddles or water seepage. The runoff water must be flowed as soon as possible out of the dwelling through the drainage system. It is important to provide retention pond, understand the canals around the location of housing and create a comprehensive drainage channel with urban drainage system. Wetlands have a weak bearing capacity, so the strength of the foundation structure is important in dwelling design. The proper foundation structure for wetland is the stilt structure, cerucuk $k^{\mathrm{i}}$ and foot plate which are good in responding the unstable soil structure. Subsequently, the water can infiltrate into the foundation structure and the whole building structure. This will cause high humidity and moisture into the building. Therefore, it is important to select appropriate building material that can respond this condition. For wooden buildings, the high quality wood is good for dwelling at wetland area. However, since the scarcity of wood, the masonry and concrete become the preferable building material. Then, the aggregate quality becomes very important. Waterproof aggregates are a necessary for dwelling design in wetlands that can reduce water filtration to the building.

For more comfortable living place, the layout of dwelling must be adapted to the conditions of puddle or regular flood at building site. Wetland as water catchment area is a place where the flood and puddle always routinely happen. Therefore, space occupancy at this site should be flexible in use, especially for area that regularly experiencing the flood or puddle. Most of riverside settlement is the one that has this situation. The space under the stilt structure should be used for activities with non permanent furniture. In case of flood, the furniture can be evacuated to higher split level inside the house. Therefore, small business activities are recommended for this space. For housing at wetland area, the proper spatial planning is easier to apply. The space order can be designed to be a growing house. The concept of house maximizes the vertical extension of the space and minimizes it so it reduces the covering the water catchment area. The building system on healthy dwelling design on wetland also adjusts to the wetland's natural conditions. To anticipate the flood, the wiring system is placed above the highest flood level. The water system must be available from independent use or PDAM services. To get a healthy natural air, appropriate ceiling high create cross ventilation inside the house.

A healthy dwelling design is relatively good looking and in accordance with the taste of occupants. To be healthy, the building appearance must suit to the Palembang local climate. To respond the tropical climate, the roof shape should be able to decrease inside temperatures; the openings should meet the principle of cross ventilation. The overall building appearance must accommodate natural daylight throughout the year and high rain fall.

\section{Conclusion}

Healthy dwelling is in a healthy environment. It can be done by considering the architectural aspects of good water drainage, suitable foundation, flexible spatial design, anticipatory building system and good appearance in accordance suit with tropical climate. In its application, creating a healthy shelter and environment in the wetlands requires the cooperation of various parties. A synergy cooperation between government policy, research institution and community in the implementation should be formed for successful effort. 


\section{References}

1. Anwar, W.F.F, The Transformation Process of Open Spaces of Riverside Villages along Musi River in Palembang (Social and Ecology, Universiti Teknologi Malaysia, 2011)

2. Anwar, W.F.F, Identification of the Morphological Characteristics of Palembang Riverside Settlement (School of Graduate Studies, Universiti Teknologi Malaysia, 2013)

3. Nugroho, S. Understanding Urban Development at Lowland Environment, Prosiding Seminar Internasional ICSSTUBN (2012)

4. Nugroho, S. Urban Morphology at Lowland Environment in Palembang, Proceeding of the 13th International conference on Sustainable Environment and Architecture (SENVAR) (2012)

5. Soendjoto, M.A Sekilas tentang lahan basah dan lingkungannya, Prosiding Seminar Universitas Lambung Mangkurat (2015)

6. Belinda A. Margono, Jean-Robert B. Bwangoy, Peter V. J. Geo-spatial Information Science 17, 1 (2014)

7. G. V. T. Matthews, The Ramsar Convention on Wetlands: its History and Development (Ramsar Convention Bureau, Gland, Switzerland, 1993)

8. Morgan, MH. Vitruvius, Ten books on Architecture (Havard University Press, 1914).

9. Mangunwijaya, Y.B Pengantar Fisika Bangunan (Djambatan, 1994)

10. Satwiko, P Fisika Bangunan (Offset Yogyakarta, 2008). 